Magdalena Duda-Seifert

Uniwersytet Wroclawski

Instytut Geografii i Rozwoju Regionalnego

Zakład Geografii Regionalnej i Turystyki

magdalena.duda-seifert@uwr.edu.pl

\title{
CHARAKTERYSTYKA TURYSTÓW KULTUROWYCH ZAINTERESOWANYCH DZIEDZICTWEM ŻYDOWSKIM W MIASTACH NA PRZYKŁADZIE ODWIEDZAJĄCYCH SYNAGOGE POD BIAŁYM BOCIANEM WE WROCŁAWIU
}

\begin{abstract}
Abstrakt: W związku z przywróceniem świetności synagodze Pod Białym Bocianem we Wrocławiu i jej udostępnieniem dla odwiedzających, a z drugiej strony promowaniem tzw. Dzielnicy Czterech Świątyń przez władze miejskie Wrocławia można założyć, że są to atrakcje turystyczne miasta wzmacniające jego wizerunek jako ośrodka wielokulturowości. Celem autorki była charakterystyka demograficzno-społeczna turystów odwiedzających synagogę, co miało pozwolić na wskazanie cech turystyki kulturowej związanej z dziedzictwem żydowskim w miastach. W wyniku przeprowadzonych badań sondażowych, uzupełnionych metodami wywiadu i obserwacji, zdefiniowano silnie zabarwiony emocjonalnie motyw poznawczy jako dominujący w tak określonym segmencie turystyki, jego międzynarodowy charakter oraz specyficzną strukturę wieku i wykształcenia. Uznano, że cechy szczególne pozwalają wyróżnić odwiedzających miejsca dziedzictwa żydowskiego jako potencjalną grupę zainteresowaną rozszerzaniem tego typu oferty, głównie w dużych miastach.
\end{abstract}

Słowa kluczowe: turystyka kulturowa, dziedzictwo żydowskie, Wrocław.

\section{WPROWADZENIE}

W ostatnich latach coraz większym zainteresowaniem naukowców cieszy się fenomen rozwoju turystyki kulturowej. W związku z tym zjawiskiem rośnie też liczba miast, w których decydenci oraz organizacje sektora pozarządowego wykorzystują dziedzictwo kulturowe w celu tworzenia nowych produktów turystycznych. W Polsce po transformacji rozpoczętej w 1989 r. odkryto na nowo odrzucane i ukrywane przez władze socjalistyczne dziedzictwo mniejszości narodowych i etnicznych. W rezultacie procesu demokratyzacji, m.in. przyjęcia Ustawy z 7 kwietnia $1989 r$. Prawo o stowarzyszeniach, która zniosła ograniczenia $\mathrm{w}$ ich rejestracji, powstało wiele związków i organizacji reprezentujących mniejszości. Od roku 1995 zaczęła rosnąć liczba wydarzeń poświęconych różnym kulturom, w tym kulturze żydowskiej. Wytyczono szlaki kulturowe, otwarto nowe muzea, a wiele obiektów odrestaurowano i nadano im funkcje kulturalno-oświatowe lub edukacyjne (DUDA-SEIFERT 2017, MAŁ-
KOWSKA-BIENIEK 2009). Najbardziej znanym wydarzeniem poświęconym mniejszości żydowskiej stał się Festiwal Kultury Żydowskiej w Krakowie (DuDA-SEIFERT 2016b, KRUCZEK 2014, WILKOŃSKA 2010), natomiast jednym $\mathrm{z}$ ważnych obiektów jest synagoga Pod Białym Bocianem we Wrocławiu pochodząca z 1829 r. Bożnica jest odrestaurowana, a jej ponowne uroczyste otwarcie w roku 1998 związane było nie tylko z przywróceniem jej funkcji religijnych, ale także z udostępnieniem dla zwiedzających (rys. 1). Powołana w 2006 r. Fundacja „Bente Kahan” dba o materialne i duchowe dziedzictwo kultury żydowskiej, dalszy rozwój tej kultury oraz aktywizację obiektów należących do gminy we Wrocławiu (http://fbk.org. pl). Założone w 2005 r. Centrum Kultury i Edukacji Żydowskiej udostępnia obecnie synagogę stale i bezpłatnie osobom indywidualnym, podczas gdy członkowie grup zorganizowanych mają obowiązek wykupienia biletu wstępu. Synagoga jest czynna od ponie- 
działku do czwartku w godzinach od 10.00 do 17.00, w piątek do 16.00 i w niedzielę od 11.00 do 16.00, z wyjątkiem świąt żydowskich, dni koncertów oraz prób (http://wroclaw.jewish.org. pl). Na pierwszej emporze w 2010 r. otwarto wystawę stałą pt. „Historia odzyskana. Życie Żydów we Wrocławiu i na Dolnym Śląsku", na drugiej pokazywane są wystawy czasowe (DUDA-SEIFERT 2016a). Dzięki temu miasto wzbogaciło się o nowy obiekt, który wpisuje się w kreowany od lat 90. minionego wieku przez władze samorządowe i elity intelektualne wizerunek wielokulturowości (DOLIŃSKA, MAKARO 2013). Poza nim w mieście można znaleźć także inne miejsca związane z dziedzictwem żydowskim i ich upamiętnienia, niemniej poza Starym Cmentarzem Żydowskim przy ulicy Ślężnej, udostępnianym jako Muzeum Sztuki Cmentarnej, pozostałe nie funkcjonują jako atrakcje turystyczne (DUDA-SEIFERT, MIKOŁAJCZAK 2012).

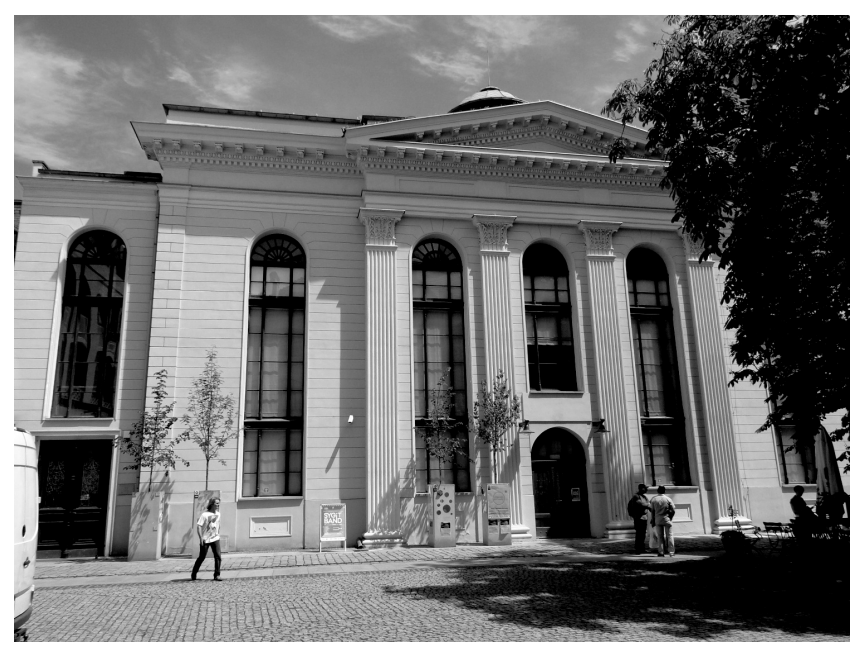

Rys. 1. Synagoga pod Białym Bocianem we Wrocławiu w 2016 r.; po lewej wejście do obiektu Fot. M. Duda-Seifert

Co jeszcze bardziej znaczące, na bazie doświadczeń przedstawicieli gminy żydowskiej zainicjowano współpracę między wspólnotami różnych wyznań, co doprowadziło do utworzenia tzw. Dzielnicy Czterech Świątyń zwanej też Dzielnicą Wzajemnego Szacunku. Jest to obszar położony między ulicami: Włodkowica, św. Antoniego, św. Mikołaja i Kazimierza Wielkiego w południowo-zachodniej części Starego Miasta, gdzie współpracują ze sobą hierarchowie i wyznawcy reprezentujący parafie: rzymskokatolicką kościoła Świętego Antoniego, ewangelicko-augsburską kościoła Opatrzności Bożej, cerkwi prawosławnej pw. Narodzenia Przenajświętszej Bogarodzicy oraz gminę żydowską skupioną wokół synagogi Pod Białym Bocianem (Dzielnica... 2010). Autorem tej inicjatywy był w 1995 r. ówczesny przewodniczący gminy żydowskiej Jerzy Kichler, a w 2002 r. zyskała ona poparcie władz miasta, dzięki czemu opracowano i uchwalono „Miejscowy plan zagospodarowania przestrzennego..." (2005). W roku 2005 powołano Fundację o nazwie Dzielnica Wzajemnego Szacunku Czterech Wyznań (http:/ / www.fundacja4wyznan.pl). W Biurze Rozwoju Wrocławia zrodziła się koncepcja Ścieżki Kulturowej Czterech Świątyń, która połączyła te obiekty, choć na razie wirtualnie, bo jej przebieg umieszczono jedynie na planie Starego Miasta na tablicy informacyjnej $u$ wejścia do Dzielnicy oraz na stronie internetowej (DUDA-SEIFERT 2016a, http://www.funda cja4wyznan.pl). Cała Dzielnica podlega rewitalizacji realizowanej wspólnie przez Urząd Miejski, wspólnoty mieszkaniowe, Zarząd Zasobu Komunalnego i lokalne fundacje (KOWALSKA 2012). Stała się ona nie tylko platformą pracy na rzecz edukacji wielokulturowej i tolerancji, ale też jest przez władze miejskie traktowana jako produkt turystyczny o unikatowym na tle innych miast polskich charakterze (GÓRALEWICZ-DROZDOWSKA, GRUSZKA 2011, http://bip.um.wroc. $\mathrm{pl} /)$.

Segmentem turystyki kulturowej zorientowanej na dziedzictwo żydowskie na przykładzie Polski zajmowano się dotąd w bardzo ograniczonym stopniu. W swoim opracowaniu A.M. ROHRSCHEIDT (2008) definiuje turystykę dziedzictwa kulturowego jako: „podróże, których głównym celem jest zetknięcie się uczestników z zabytkami, zespołami i miejscami uznanymi oficjalnie i powszechnie za dziedzictwo kulturowe świata, kraju lub regionu" (ROHRSCHEIDT 2008, s. 53). Na wybór odwiedzanych obiektów mają według niego wpływ m.in. ich unikatowość, stan zachowania oraz dostępność. Turystów takich A.M. ROHRSCHEIDT (2008) określił w większości jako „motywowanych kulturowo", najczęściej w wieku średnim lub starszym i z wyższym wykształceniem, dobrze zorientowanych w europejskim dziedzictwie kulturowym, często mających doświadczenia $z$ innych odwiedzanych krajów. Drugą grupę stanowią według niego „turyści zainteresowani kulturowo”, dla których spotkania z pomnikami dziedzictwa są jednym z licznych punktów urozmaiconego programu zwiedzania. Obiekty dziedzictwa żydowskiego mogą stanowić również cel odwiedzin $\mathrm{w}$ ramach tzw. turystyki etnicznej, czyli „podejmowanej przez uczestników do krajów lub miejsc pochodzenia własnego lub osób bliskich lub związanych z tożsamością etniczną własną lub rodziny" (ROHRSCHEIDT 2008, s. 108).

Potencjałem dziedzictwa żydowskiego w Polsce dla turystyki zajęła się w swoim artykule E. MAŁKOWSKA-BIENIEK (2009). Wspomina ona o liczbie odwiedzających cmentarze żydowskie, w tym o 5300 osobach w 2008 r. na Cmentarzu Żydowskim we Wrocławiu. Wskazuje również na wysoką frekwencję w Starej Synagodze na krakowskim Kazimierzu około 86 tys. osób w roku 2008, oraz na wzrost liczby od- 
wiedzających Kamienicę Celejowską, eksponującą malarskie pejzaże żydowskiego Kazimierza, z 12 tys. w 2006 r. do 16 tys. w 2008. B. GŁADYŚ (2009) analizujacc zjawisko turystyki żydowskiej w Polsce, wskazuje również na wzrost tego ruchu do blisko 70 tys. w roku 2007. Głównym celem tego typu podróży jest odwiedzanie miejsc martyrologii oraz miejsc związanych z historią narodu żydowskiego w Polsce. Wrocław jednak nie został przez nią wymieniony jako jeden $\mathrm{z}$ celów zorganizowanych podróży $\mathrm{w}$ ramach turystyki etnicznej. Próbę oceny dziedzictwa żydowskiego w Polsce w kontekście produktu turystycznego podjął również L. KOZŁOWSKI (2013). Uważa on, że jedynym dojrzałym, kompletnym i rzeczywistym produktem turystycznym tego typu jest krakowski Kazimierz, podczas gdy np. Łódź żydowska jest produktem dopiero kształtowanym. Podaje on liczbę odwiedzających Starą Synagogę na Kazimierzu wynoszącą prawie 120 tys. w roku 2012, co w porównaniu z danymi E. Małkowskiej-Bieniek, cytowanymi powyżej, wskazuje na dalszy wzrost odwiedzin w ostatnich latach $\mathrm{w}$ tempie średnio $10 \%$ rocznie. Wyniki badań na temat oceny zachowań konsumenckich osób zainteresowanych judaikami opublikowała A. WILKOŃSKA (2010). Dotyczyły one jednak tylko grupy wyłonionej $\mathrm{z}$ szerokiego spektrum respondentów odwiedzających Kraków i Łódź w 2008 r., a nie były badaniami ukierunkowanymi wyłącznie na segment odwiedzających miejsca związane z dziedzictwem żydowskim. Wśród wymienianych obiektów przez osoby badane w Krakowie na pierwszym miejscu znalazły się synagogi (ok. połowa wskazań). W Łodzi synagogę wskazało tylko kilka procent odwiedzających krajowych, co wynika z różnej liczby tych obiektów zachowanych w obu miastach. Brak jednak dotąd kompleksowych opracowań poświęconych analizie rynku, a więc osób odwiedzających polskie judaika, odpowiadających na pytanie, jaki rodzaj ruchu turystycznego generuje ta oferta? Autorka w niniejszym opracowaniu stara się wypełnić tę lukę w postaci pierwszego z cyklu planowanych badań poświęconych temu zjawisku.

\section{CEL I METODY}

Celem autorki była charakterystyka demograficzno-społeczna turystów kulturowych zainteresowanych dziedzictwem żydowskim w miastach na przykładzie odwiedzających synagogę Pod Białym Bocianem we Wrocławiu. Badania miały przynieść odpowiedź na pytania, w jakim stopniu synagoga ta jest rzeczywistą atrakcją turystyczną miasta, jakich turystów obiekt ten przyciąga i dlaczego oraz jakie są cechy tego segmentu turystyki kulturowej zorientowanej na poznawanie dziedzictwa żydowskiego dużych miast? Autorka przyjęła hipotezę o występowaniu cech charakterystycznych dla tak określonej grupy i silnej motywacji poznawczej jej reprezentantów. Posłużono się metodą sondażu diagnostycznego $\mathrm{z}$ zastosowaniem techniki ankietowej w oparciu o opracowany kwestionariusz. Jako uzupełniające metody wykorzystano także obserwacje i wywiady nieustrukturyzowane przeprowadzone z przedstawicielami gminy żydowskiej, zatrudnionymi przy obsłudze ruchu turystycznego w synagodze.

Kwestionariusz zawierał, poza tzw. metryczką, 19 pytań, w tym $18 \mathrm{z}$ podaną kafeterią odpowiedzi i jedno pytanie otwarte dotyczące odczuć towarzyszących respondentowi w trakcie zwiedzania synagogi. Pytania odnosiły się do kilku zagadnień, a mianowicie charakterystyki ogólnej ankietowanych turystów, motywacji i odczuć związanych z wizytą w synagodze oraz zainteresowania innymi miejscami i wydarzeniami związanymi z dziedzictwem żydowskim we Wrocławiu i w Polsce. Kwestionariusz ankiety opracowano w trzech wersjach językowych - polskiej, angielskiej i niemieckiej, co spowodowało, że praktycznie wszyscy chcący wypełnić ankietę mogli to zrobić.

Badania przeprowadzono w 2016 r.: 16 i 17 sierpnia (odpowiednio: 37 i 31 ankiet) oraz 7 i 8 września (26 i 27 ankiet), a także 16 i 18 września (15 i 32 ankiety). Celowo wybrano różne dni tygodnia, żeby uwzględnić przyjezdnych wykorzystujących różne terminy oraz połączenia komunikacyjne, a były to: wtorek, środa (dwa razy), czwartek, piątek i niedziela. Populację poddaną badaniu ograniczono do osób zwiedzających synagogę indywidualnie ze względu na fakt samodzielnego podejmowania przez nich decyzji o wyborze tego obiektu, w przeciwieństwie do grup realizujących program organizatora. Zdecydowano także o wykluczeniu osób zamieszkałych we Wrocławiu ze względu na cel, jakim było określenie charakterystyki turystów. Uwzględniono natomiast tzw. odwiedzających jednodniowych, gdyż uznano, że także ta grupa tworzy popyt turystyczny i stanowi liczną grupę konsumentów turystyki kulturowej (ROHRSCHEIDT 2008).

Zastosowana metoda doboru nielosowego celowego polegała na zaproszeniu do badania jednej osoby z każdej odwiedzającej grupy i każdej z osób zwiedzających synagogę samotnie. Wypełnienia ankiety odmówiło jedynie kilka osób, tłumacząc się ograniczeniem czasowym. Ankieterka przebywała w obiekcie w wybrane dni w godzinach otwarcia. Średnią liczbę indywidualnych odwiedzających na podstawie obserwacji określono na około 80-90 osób na dzień w sezonie letnio-jesiennym, dlatego też jeśli liczba wypełnionych kwestionariuszy liczyła około 30 dziennie (z wyjątkiem 16 września, gdy czas przeprowadzania badań był krótszy), próbę tę uznano za reprezentatywną dla określonej populacji badawczej. W sumie w cią- 
gu sześciu dni zgromadzono 168 pełnych kwestionariuszy, które następnie poddano analizie. Wyniki zostały zaprezentowane poniżej w postaci opisu oraz zamieszczonych rysunków opracowanych przez autorkę.

\section{CECHY DEMOGRAFICZNE RESPONDENTÓW I CHARAKTER ICH POBYTU TURYSTYCZNEGO WE WROCŁAWIU}

Większość respondentów stanowiły kobiety (57\%). Dominowali ludzie powyżej 60. roku życia, następnie duży udział w badanej populacji miały osoby dojrzałe oraz starsze, ale jeszcze w wieku przedemerytalnym, tylko mniej niż $1 / 4$ badanej grupy nie przekroczyła granicy 30 lat (rys. 2). Taka struktura wieku odpowiada wskazaniom A.M. ROHRSCHEIDTA (2008) w odniesieniu do grupy turystów motywowanych kulturowo.

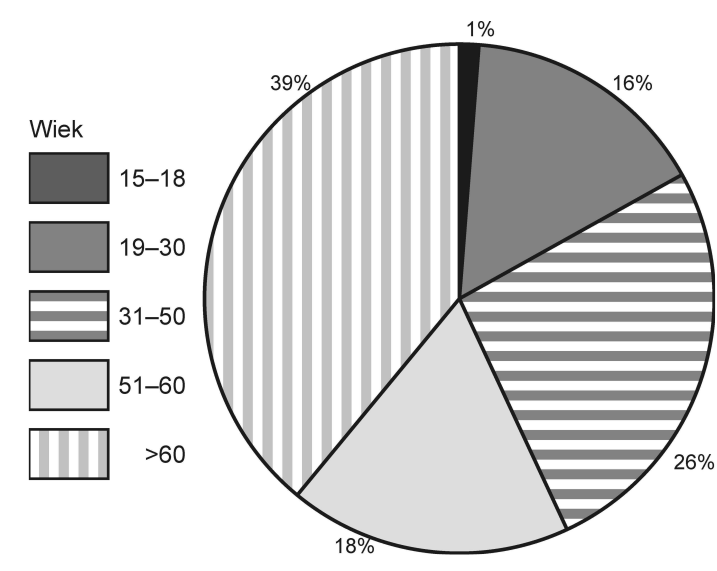

Rys. 2. Struktura wieku respondentów Źródło: opracowanie własne

Ponad połowę badanej grupy stanowiły osoby aktywne zawodowo (54\%), duży był także udział emerytów i rencistów (33\%), co pozostawało w koherencji ze strukturą wieku. Jedynie co 10 . osoba była studentem lub uczniem. Profil wykształcenia odwiedzających synagogę potwierdza cytowaną w literaturze charakterystykę turystów kulturowych (WILKOŃSKA 2010), ponieważ tylko $12 \%$ respondentów legitymowało się wykształceniem średnim, podczas gdy ponad $3 / 4$ licencjatem, magisterium albo tytułem inżyniera lub było w trakcie studiów. Założenie autorki o szczególnie wysokim odsetku osób z wykształceniem wyższym znalazło potwierdzenie również w wysokiej liczbie wskazań na uzyskanie przez respondentów stopnia doktora nauk (rys. 3).

Prawie $3 / 4$ respondentów pochodziło z zagranicy, najliczniejszą grupę stanowili Niemcy, dopiero drugą co do wielkości Polacy. Kolejne trzy kraje najliczniej reprezentowane to Izrael, USA i Wielka Brytania, po trzy osoby przybyły z Danii, Belgii i Turcji (rys. 4). W grupie badawczej znaleźli się też przedstawiciele Francji, Holandii, Szwecji, Włoch, Hiszpanii, Austrii i Kanady. Prześledzenie wpisów w Księdze Pamiątkowej wyłożonej przy wejściu na wystawę pozwoliło zauważyć reprezentantów także innych krajów niż ujęte w badaniu, np. Szwajcarii, Rosji, Indonezji i Chile. Mniejszy niż się spodziewano był odsetek osób o własnych lub rodzinnych powiązaniach $\mathrm{z}$ miastem czy z synagoga, co jest na pewno uwarunkowane trudną historią zarówno Holocaustu, jak i wymuszonej przez władze polskie emigracji mniejszości żydowskiej w latach powojennych. Niemniej jednak, na co zwracała uwage Justyna Molasy-Dumais z Centrum Informacji Żydowskiej, dość duża liczba tzw. breslauerowców przetrwała Holocaust, ponieważ dostatecznie wcześnie ostrzeżona kierunkiem, w jakim zmierzała polityka wewnętrzna Niemiec, zdążyła wyemigrować. Dzisiaj więc potomkowie dawnych mieszkańców miasta rozsiani są $\mathrm{w}$ wielu krajach świata, m.in. w Stanach Zjednoczonych, Izraelu czy Australii.
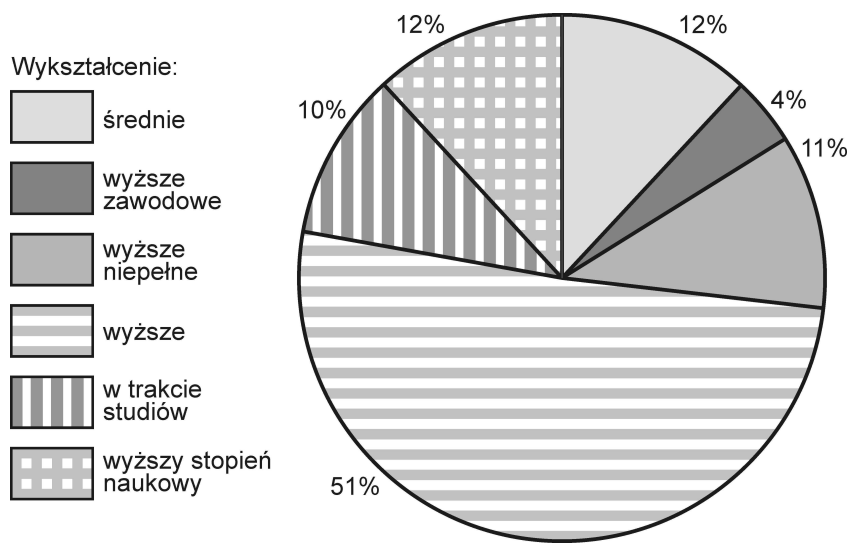

Rys. 3. Struktura wykształcenia respondentów Źródło: opracowanie własne

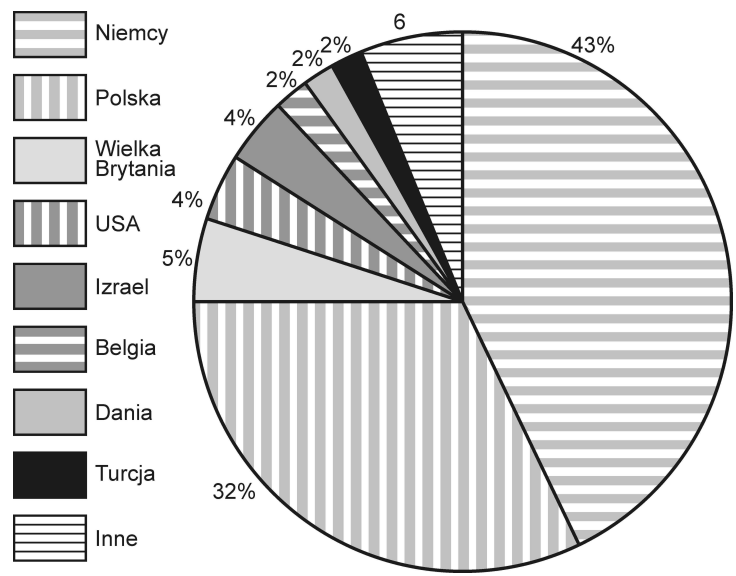

Rys. 4. Pochodzenie terytorialne respondentów Źródło: opracowanie własne 
Liczebność przedstawicieli niektórych krajów wśród odwiedzających zwiększała dostępność komunikacyjna - Niemcy z Drezna deklarowali skorzystanie z sobotnio-niedzielnego połączenia kolejowego z Wrocławiem - otwartego z okazji roku, w którym Wrocław pełni funkcję Europejskiej Stolicy Kultury. Anglicy z południowo-zachodniej Anglii skorzystali z przelotów tanimi liniami oferowanymi w weekendy. Polacy, w liczbie 54, przybyli do Wrocławia z 12 województw, niereprezentowane były jedynie lubuskie, lubelskie, łódzkie i podlaskie. 73 Niemców pochodziło z wszystkich landów niemieckich, $\mathrm{z}$ przewagą mieszkańców Berlina (11 osób), Saksonii (10 osób) i Nadrenii-Westfalii (9), czyli z obszarów blisko położonych i oferujących dogodne połączenia komunikacyjne lub, jak w przypadku stolicy i ostatniego z wymienionych - o dużym potencjale ludnościowym.

Aż 113 osób (67\%) było we Wrocławiu po raz pierwszy, ale 55 osób przybyło do miasta po raz kolejny $(33 \%)$.

Najważniejszym motywem przyjazdu do Wrocławia było typowe dla krajoznawstwa zwiedzanie (62\%). Kolejne trzy, o podobnej liczbie wskazań, to: odwiedziny przyjaciół i krewnych, odwiedziny o charakterze sentymentalnym oraz udział w wydarzeniu kulturalnym (każdy z motywów deklarowało odpowiednio 19, 18 i 18 osób, a więc po ok. 11\% badanych). 18 ankietowanych wskazało charakter sentymentalny podróży w związku z powiązaniami rodziny lub własnymi z miastem, przy czym dotyczyły one także wspomnień z okresu studiów czy wcześniejszych etapów edukacji. Sześciu respondentów mieszkało we Wrocławiu w okresie powojennym, a czterech było potomkami mieszkających $\mathrm{w}$ mieście przed drugą wojną światową. Potwierdza to wyniki innych badań, wskazujących, że poznawcze i sentymentalne pobudki kierują osobami przyjeżdżającymi w ramach tzw. turystyki żydowskiej, choć w tym przypadku byli to też Niemcy pochodzący z Dolnego Śląska (GŁADYŚ 2009). Troje ankietowanych przyjechało chcąc wziąć udział w wydarzeniu kulturalnym podkreślając związek wybranych koncertów z programem Europejskiej Stolicy Kultury (ESK), raz w przypadku zwiedzania miasta, jako ogólny motyw podjęcia takiej podróży podano pełnienie przez miasto funkcji ESK. Jedna $z$ respondentek przyjechała, aby wziać udział w międzynarodowej Deborah Conference - organizowanej po raz ósmy, tym razem we Wrocławiu w dniach od pierwszego do czwartego września przez Fundację Bente Kahan wraz z berlińską organizacją Bet Debora i krakowskim stowarzyszeniem Czulent na temat: "Creating Alternatives for Jewish Women in Europe" (https:// www.bet-debora.net/). Jedynie ośmiu respondentów wskazało jako motyw podróży interesy lub pracę (5\%).
Respondenci najczęściej podróżowali z członkiem rodziny (37\%), w większości przypadków z partnerem. Na drugim miejscu znalazło się towarzyszenie przyjaciołom (29\%). Znaczny był też udział osób uprawiających turystykę większą grupą rodzinną (13\%) lub samotnie (14\%). Zwłaszcza ta ostatnia formuła jest cechą charakterystyczną „podróży kulturowej” lub odwiedzin przyjaciół i znajomych. 12 osób wskazało na podróż w towarzystwie i partnera i grupy przyjaciół $(7 \%)$.

Ankietowani najczęściej odwiedzali Wrocław w trakcie podróży trwającej od dwóch do trzech dni lub od czterech dni do tygodnia (odpowiednio 35 i $37 \%$ ). Na trzecim miejscu znalazła się grupa osób spędzających w podróży czas od ośmiu dni do dwóch tygodni (14\%). 8\% stanowili tzw. odwiedzający jednodniowi (14 osób).

Zaskakujące były wyniki dotyczące czasu przeznaczonego na pobyt we Wrocławiu. Okazało się, że większość osób, bo aż 61 (36\%) spędzało we Wrocławiu co najmniej cztery dni, na kolejnych miejscach znaleźli się badani pozostający w mieście na dwa lub trzy dni (po 26\%), jedynie 20 osób przyjechało tylko na jeden dzień (12\%). Wyniki te są bardzo korzystne z punktu widzenia władz miasta oraz przedsiębiorców działających w branży turystycznej, bo oznaczają, że jest ono atrakcyjne na dłuższy pobyt.

\section{LICZBA ODWIEDZAJACCYCH, MOTYWACJE I WRAŻENIA ZWIAZZANE Z ODWIEDZINAMI W SYNAGODZE}

Liczbę odwiedzających synagogę Pod Białym Bocianem na podstawie obserwacji własnych oraz wywiadu z Justyną Molasy-Dumais i informacji Jerzego Kichlera oszacowano na około 21 tys. rocznie, przy czym około połowę stanowią odwiedzający indywidualni. Jest to mniej niż 1/5 liczby zwiedzających Starą Synagogę w Krakowie (KOZŁOWSKI 2013), co można wytłumaczyć krótszym okresem jej funkcjonowania jako atrakcji turystycznej i dużo mniejszą skalą promocji. Mimo wszystko we Wrocławiu liczba ta jest porównywalna do liczby odwiedzających muzea tzw. drugiej kategorii pod względem ich atrakcyjności turystycznej (np. Etnograficzne - 26 tys. czy Poczty i Telekomunikacji - 23 tys. w 2013 r.) (DUDA-SEIFERT 2011, Rocznik statystyczny Wrocławia 2014). Według słów J. Molasy-Dumais można obserwować wzrost ruchu turystycznego w ostatnich latach i pojawianie się większych grup odwiedzających pochodzących z krajów, z którymi linie lotnicze operujące na wrocławskim lotnisku otworzyły nowe bezpośrednie połączenia. 
Źródłem informacji respondentów o synagodze były w największym zakresie przewodniki drukowane, m.in. Dolny Śląsk J. CZERWIŃSKIEGO (2009), Spacerownik... B. MACIEJEWSKIEJ (2008) oraz w językach obcych - z serii Dumont, City, Baedecker, Lonely Planet. Jest to najprawdopodobniej efekt znacznego udziału starszych osób, które sięgają raczej po tradycyjne źródła informacji turystycznej. Na drugim miejscu znalazł się Internet, dość duża grupa osób kierowała się także rekomendacją znajomych lub krewnych (rys. 5). Spośród respondentów, którzy wskazali inne źródło, pięciu dowiedziało się przypadkiem podczas zwiedzania miasta, sześciu - od przewodników miejskich, m.in. podczas FreeWalking Tours, dwoje deklarowało ogólną wiedzę z zakresu historii, a troje wskazało własną wiedzę wynikającą ze szczególnego zainteresowania kulturą żydowską.

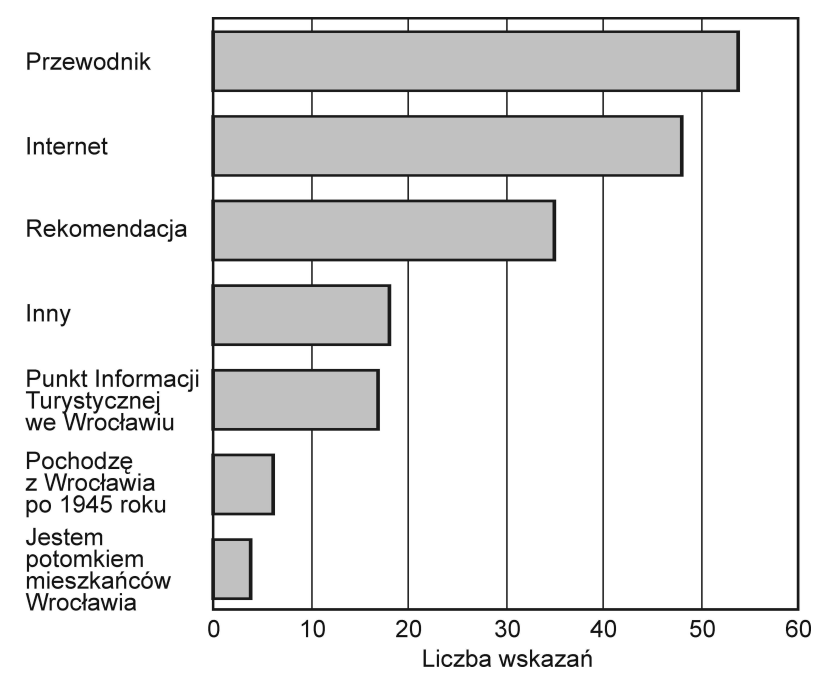

Rys. 5. Źródło informacji o synagodze Pod Białym Bocianem (odpowiedzi nie sumują się do $100 \%$ )

Źródło: opracowanie własne

Powód wizyty w synagodze w największym stopniu wiązał się z zainteresowaniem kulturą żydowską, bowiem 110 respondentów wskazało je jako główny. Dla około $1 / 3$ badanych synagoga stanowiła jeden $\mathrm{z}$ ciekawych i wartych poznania zabytków miasta, podczas gdy dla 10 badanych wiązała się przede wszystkim z historią osobistą bądź rodziny (6\%). Wśród innych motywów dwie osoby wymieniły ogólne zainteresowanie historią, jedna została przyprowadzona przez przyjaciółkę.

O Dzielnicy Czterech Świątyń wcześniej słyszało tylko 25 respondentów (15\%), w tym 10 z Polski, co świadczy o ciągle nieznacznym zaistnieniu tej atrakcji turystycznej w świadomości potencjalnych odwiedzających. Chęć zwiedzania całej Dzielnicy zadeklarowało 98 osób (58\%), w tym większość, bo aż 20 spośród tych, które słyszały o niej przed przyjazdem. Niestety, z rozmów z odwiedzającymi synagogę wynikało, że ci, którzy już taki plan zrealizowali, narzekali i na niedostatek informacji $\mathrm{w}$ terenie, $\mathrm{i}$ na brak możliwości wejścia do dwóch z pozostałych trzech świątyń wchodzących w skład Dzielnicy, czyli cerkwi prawosławnej i kościoła ewangelicko-augsburskiego.

Synagoga Pod Białym Bocianem wywarła pozytywne wrażenie na przeważającej liczbie ankietowanych, gdyż tylko sześć osób z tej grupy stwierdziło, że nie zarekomendowałoby jej swoim znajomym czy krewnym. W jednym przypadku respondent uznał, że choć obiekt jest ładny i zadbany, nie był wart odwiedzin, bowiem jego zdaniem jest to "nic specjalnego”. W dwóch przypadkach powodem niskiej oceny był brak objaśnień $w$ języku niemieckim na wystawie stałej czy też brak audioprzewodnika, raz wskazano przygnębiający charakter wystawy, raz padło określenie "daleko od wszystkiego", co trudno wytłumaczyć, gdyż synagoga jest położona w odległości pieszego spaceru od Rynku Starego Miasta. W jednym przypadku respondent nie podał przyczyny braku chęci polecenia obiektu.

Profil odwiedzających synagogę można przedstawić jako osoby aktywnie i refleksyjnie podchodzące do odwiedzanych miejsc, gdyż aż 128 respondentów (76\%) podzieliło się swoimi wrażeniami w odpowiedzi na pytanie otwarte. Opinie te dotyczyły piękna i bardzo dobrego stanu utrzymania samego budynku, walorów informacyjnych wystawy, ale w równie szerokim zakresie także wzbudzanych emocji (przygnębienia, smutku, poruszenia). Deklarowano także konieczność szacunku i tolerancji wobec innych narodów, radość $z$ powodu odtworzenia życia gminy żydowskiej we Wrocławiu. Dawni byli mieszkańcy miasta mówili o przeżytym głębokim wzruszeniu towarzyszącemu jej zwiedzaniu i radości z tego powodu, że zadbano o synagogę oraz że miejsce to "żyje". Wskazywano na potrzebę uzupełnienia wystawy o objaśnienia $\mathrm{w}$ języku niemieckim, opracowania i zaproponowania pieczątki pamiątkowej czy też rozszerzenia oferty o możliwość oglądania filmów poświęconych historii żydowskiej wspólnoty we Wrocławiu.

\section{ZAINTERESOWANIE INNYMI JUDAIKAMI WE WROCEAWIU I W POLSCE}

Mniej niż połowa respondentów deklarowała odwiedzenie jeszcze innego obiektu związanego z kulturą żydowską we Wrocławiu (71 osób, tj. 42\%). Najczęściej spośród zaproponowanych obiektów wybierano Stary Cmentarz Żydowski, który stanowi Oddział Muzeum 
Miejskiego Wrocławia (rys. 6). Często w trakcie przeprowadzania badań ankietowani pytali o jego lokalizację i możliwość dojazdu, ale wielekrotnie zniechęcały ich do odwiedzin odległe położenie i trudności w dotarciu komunikacją miejską. Inne najczęściej zaznaczane upamiętnienia obecności mniejszości żydowskiej to położony tuż obok wejścia do dzielnicy Czterech Świątyń Pomnik Bohaterów Getta Warszawskiego oraz trudny do odnalezienia pomnik poświęcony zniszczonej w trakcie Nocy Kryształowej 1938 r. synagodze $\mathrm{Na}$ Wygonie. Kolejnym miejscem wartym odwiedzenia okazał się tzw. Nowy Cmentarz Żydowski przy ulicy Lotniczej, założony w roku 1898, a funkcjonujący obecnie jako miejsce pochówku członków gminy żydowskiej, jednak z tego względu trudno dostępny dla odwiedzających. Wśród innych obiektów i miejsc upamiętnienia historii Żydów we Wrocławiu jedna osoba wymieniła także te związane $\mathrm{z}$ życiem Edyty Stein, która urodziła się $\mathrm{w}$ rodzinie niemieckich Żydów, ale po konwersji wstąpiła do zakonu karmelitanek. Po kanonizacji została ogłoszona przez Kościół katolicki patronką Europy (http://www.edyta stein.org.pl).

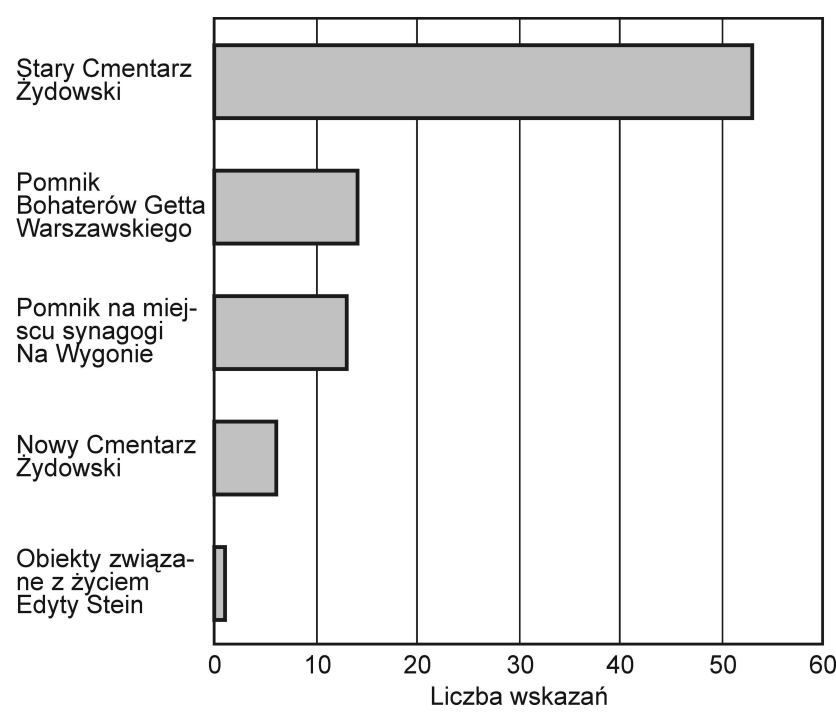

Rys. 6. Zainteresowanie respondentów innymi obiektami i upamiętnieniami związanymi z historią Żydów we Wrocławiu (wg liczby wskazań)

Źródło: opracowanie własne

Z wybranej formy zwiedzania miasta $z$ przewodnikiem skorzystała $1 / 4$ badanych (42 osoby), przy czym tylko w sześciu przypadkach tematem była Dzielnica Czterech Świątyń, a w dwóch historia żydowskich mieszkańców miasta.

W kwestionariuszu zawarto także pytanie o znajomość opartego na kulturze żydowskiej festiwalu Simcha, organizowanego przez Fundację Pro Arte, który w 2016 r. odbył się po raz 18. (DUDA-SEIFERT
2017). Okazało się jednak, że jest on jeszcze mniej rozpoznawalny niż Dzielnica Czterech Świątyń, bo jedynie przez 13 respondentów (8\%).

Duża grupa spośród ankietowanych odwiedziła lub planowała odwiedzić inne miejsca w Polsce związane z historią i kulturą żydowską. Było to aż 110 osób, tj. 65\% badanej grupy, czyli więcej niż w przypadku deklarowania chęci zwiedzania judaików we Wrocławiu. Najczęściej spośród zasugerowanych miejsc wybierano Kazimierz w Krakowie i obiekty w Warszawie (rys. 7). Wśród tzw. innych w pytaniu otwartym najczęściej podawano dawny nazistowski obóz koncentracyjny w Auschwitz (Oświęcimiu) oraz inne miejsca zagłady i martyrologii Żydów, takie jak Majdanek, Treblinka, Bełżec, Sztutowo czy Jedwabne. Wskazywano także na duże miasta - Łódź, Lublin, Gdańsk czy Białystok, oraz mniejsze ośrodki, często znane z judaików - m.in.: Tykocin, Leszno, Włodawa, Zamość, Szczebrzeszyn, Kazimierz Dolny, Biłgoraj, Chmielnik i Dzierżoniów. W ankiecie kilka osób wpisało, poza synagogami (w Przysusze czy Tykocinie), cmentarze żydowskie albo jako kategorię miejsc, albo wskazując na konkretne obiekty (w Sopocie, Głogowie, Szlichtyngowej). Pojedynczy badani wspomnieli także w rozmowie o tym, że odwiedzili miejsca związane z kulturą żydowską poza Polską, w takich miastach, jak Praga, Budapeszt czy Ryga.

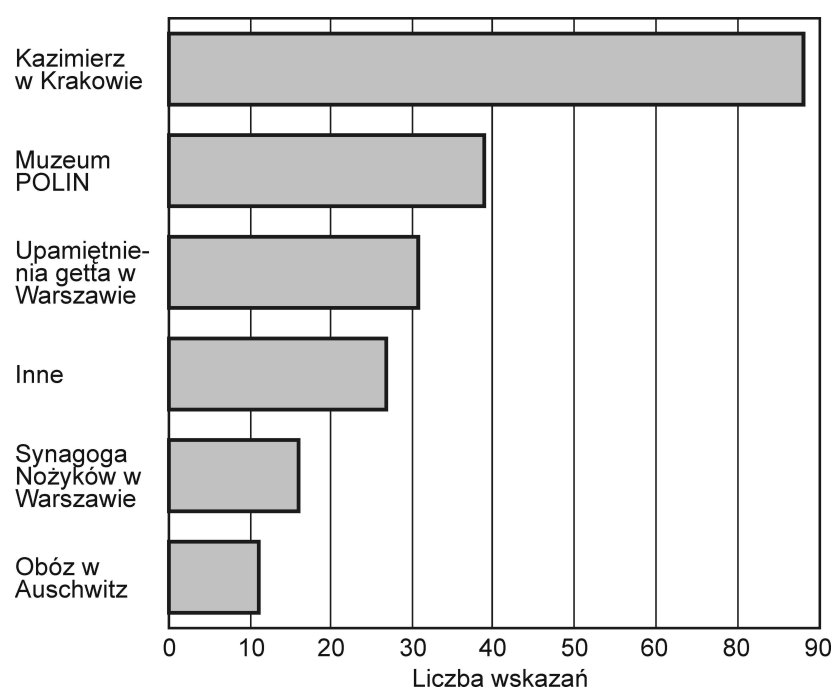

Rys. 7. Znajomość innych miejsc dziedzictwa żydowskiego w Polsce deklarowana przez respondentów

(według liczby wskazań - odpowiedzi nie sumują się do 168) Źródło: opracowanie własne

Wyniki badań przeprowadzonych we wrocławskiej synagodze potwierdziły także rangę Żydowskiego Festiwalu Kultury w Krakowie, uważanego za najbardziej znane wydarzenie w Polsce poświęcone kulturze żydowskiej, a wiedzą na jego temat wykazał się co drugi ankietowany (84 osoby). 


\section{WNIOSKI}

Przeprowadzone w sierpniu i wrześniu 2016 r. badania sondażowe w synagodze Pod Białym Bocianem we Wrocławiu pozwoliły na opracowanie ogólnej charakterystyki turystów ją odwiedzających, a szczególnie na wyjaśnienie motywacji i emocji związanych z wizytą w synagodze oraz na określenie stopnia zainteresowania innymi obiektami dziedzictwa żydowskiego we Wrocławiu i w Polsce. Cechy te można uogólnić i przyjąć jako charakterystyczne dla specyficznego segmentu turystów kulturowych zainteresowanych dziedzictwem żydowskim w miastach polskich.

Grupa osób zwiedzających synagogę wyróżnia się na tle ogółu turystów odwiedzających Dolny Śląsk (Badanie ruchu... 2015). Wyższy jest w niej udział osób starszych i emerytów, a także mających wykształcenie wyższe. Są to cechy typowe dla segmentu turystyki kulturowej. Zdecydowanie zwraca też uwage silne umiędzynarodowienie tej grupy turystów. Największy odsetek stanowią w niej Niemcy, co wynika ze specyficznego charakteru obiektu, reprezentującego XIX-wieczną i późniejszą historię miasta położonego do 1945 r. w granicach Niemiec. Bardzo szeroki jest zasięg geograficzny miejsc pochodzenia turystów odwiedzających synagogę nie tylko co do liczebności krajów, ale też regionów administracyjnych w przypadku Polski i Niemiec. Ciekawą cechą okazała się więc wielonarodowość i wielokulturowość segmentu turystów kulturowych zainteresowanych dziedzictwem żydowskim.

Kolejną cechą szczególną wydaje się również bardzo duże zainteresowanie i zaangażowanie emocjonalne w poznawanie odmiennej kultury, o czym świadczyły wypowiedzi udzielone na pytanie otwarte przez odwiedzających oraz w trakcie rozmów z autorką. Motyw poznawczy był wymieniany najczęściej, co świadczy o dużym potencjale synagogi jako unikatowego "reprezentanta" zniszczonego w większości dziedzictwa materialnego mniejszości żydowskiej, która wniosła ogromny wkład w rozwój miasta w przeszłości i stanowiła element jego wielokulturowej tożsamości. Ogromne pozytywne emocje wśród odwiedzających były generowane nie tylko w związku z unikatowością obiektu, ale i ze względu na jakość dzieła architektury oraz doskonały stan odrestaurowanego zabytku, jak i prezentowane zwłaszcza na wystawie walory edukacyjne. Budujące jest zainteresowanie przedstawicieli innych religii judaizmem, ich otwartość na wiedzę, a także deklarowane wartości tolerancji oraz szacunku dla mniejszości narodowych i religijnych.

Badania potwierdziły kryteria determinujące wybór danego obiektu dziedzictwa żydowskiego jako celu odwiedzin turystycznych - jego unikatowość, dostępność oraz dobry stan zachowania.

Niestety, niski okazał się poziom wiedzy odwiedzających na temat innych upamiętnień i śladów dziedzictwa żydowskiego we Wrocławiu, poza jedynie Starym Cmentarzem Żydowskim. Praktycznie nieznany szerzej pozostaje jedyny festiwal poświęcony kulturze żydowskiej na Dolnym Śląsku, jakim jest Simcha. Okazało się również, że Dzielnica Czterech Wyznań nie może być traktowana jako produkt turystyczny ze względu na to, że jest prawie nieznana. Nawet gdy jest odwiedzana, przeważają opinie krytyczne związane ze słabą dostępnością i oznakowaniem proponowanych do odwiedzenia obiektów.

Kolejna cecha reprezentowana przez większość osób badanych potwierdza tezę A.M. ROHRSCHEIDTA (2008) o szerszej wiedzy i doświadczeniu turystów kulturowych odwiedzających obiekty dziedzictwa w zakresie określonej tematyki. Co najmniej co drugi respondent wykazał się bowiem wiedzą na temat innych miejsc w Polsce związanych z dziedzictwem żydowskim, które już odwiedził lub planował zobaczyć, a niektórzy wspominali $\mathrm{w}$ rozmowie $\mathrm{z}$ autorką także obiekty żydowskie odwiedzane w innych dużych miastach Europy Środkowo-Wschodniej. Ponad połowa badanych słyszała również o Festiwalu Kultury Żydowskiej w Krakowie.

Reasumując badania przeprowadzone we Wrocławiu w synagodze Pod Białym Bocianem można stwierdzić, że miejsce to jest niezwykle ważne w ofercie turystycznej miasta, a obiekt znajduje się w doskonałym stanie, jest w pełni udostępniony i prezentuje bogate treści edukacyjne. Można uznać, że jest jedną $z$ atrakcji turystycznych miasta o frekwencji porównywalnej z muzeami o średniej atrakcyjności. Przyciąga on jednak specyficzny segment turystów kulturowych odwiedzających miasta, ale zaspokaja ich potrzeby w znacznym stopniu, niosąc jednocześnie głębsze przesłanie. Jest to bowiem międzynarodowa społeczność, wielokulturowa, lecz zainteresowana kulturą odmienną, o bardzo silnych motywacjach poznawczych i $z$ reguły zaangażowana emocjonalnie oraz deklarująca w większości szacunek do mniejszości religijnej, jaką są wyznawcy judaizmu. Tak określona grupa może stać się podstawą do rozwoju turystyki opartej na obiektach i upamiętnieniu dziedzictwa żydowskiego w Polsce, przy czym na pewno ten specyficzny segment turystyki kulturowej wymaga dalszych badań.

\section{BIBLIOGRAFIA}

Badanie ruchu turystycznego na Dolnym Śląsku w ujęciu powiatowym i subregionalnym wg "Aktualizacji programu rozwoju turystyki dla województwa dolnośląskiego. Raport końcowy", 2015, Biostat Grupa, http:/ / www.umwd.dolnyslask.pl/fileadmin 
/user_upload/Turystyka/Dokumenty/Badanie_ruchu_tur ystycznego_na_Dolnym_Slasku_w_2015_r.pdf; 27.10.2016.

CZERWIŃSKI J., 2009, Dolny Śląsk, Ekograf, Wrocław.

DOLIŃSKA K., MAKARO J., 2013, Medialne aspekty wielokulturowości Wroctawia, „Media i Społeczeństwo”, 3, s. 149-166.

DUDA-SEIFERT M., 2011, Ocena atrakcyjności muzeów Wroctawia dla turystyki kulturowej, [w:] Turystyka kulturowa na Dolnym Ślqsku - wybrane aspekty, t. II, K. Widawski (red.), Instytut Geografii i Rozwoju Regionalnego we Wrocławiu, Wrocław, s. 171-194.

DUDA-SEIFERT M., 2016a, Walory poznawcze miejsc kultu i zgromadzeń mniejszości religijnych Wroctawia, [w:] Kultura i turystyka - sacrum i profanum, J. Latosińska, J. Mokras-Grabowska (red.), Regionalna Organizacja Turystyczna Województwa Łódzkiego, Łódź, s. 221-239.

DUDA-SEIFERT M., 2016b, Wydarzenia jako etniczna atrakcja kulturowa - nowy trend w turystyce eventowej - na przyktadzie mniejszości żydowskiej w Polsce, Zeszyty Naukowe Uniwersytetu Szczecińskiego „Ekonomiczne Problemy Turystyki”, 1 (33), s. 235-246.

DUDA-SEIFERT M., 2017, Wydarzenia zwiazane z mniejszościami narodowymi i etnicznymi na Dolnym Śląsu a ich wykorzystanie w promocji turystycznej regionu, [w:] Ożywianie przestrzeni turystyki kulturowej, D. Orłowski (red.), Wyd. WSTIJO, Warszawa (w druku).

DUDA-SEIFERT M., MiKOŁAJCZAK T., 2012, Żydowskie miejsca kultu i cmentarze Wroctawia - zmiany w czasie i przestrzeni, [w:] Studia krajobrazowe. Krajobrazy zdefiniowane - znaki $i$ symbole w krajobrazie, J. Łach, A. Zaręba (red.), Wyd. Uniwersytetu Wrocławskiego, Wrocław, s. 85-104.

Dzielnica Czterech Wyznań, 2010, pr. zbiorowa, Wyd. C2 i Fundacja Dzielnica Wzajemnego Szacunku Czterech Wyznań, Wrocław.

GŁADYŚ B., 2009, Turystyka Żydów do Polski po 1990 roku. „Prace Geograficzne", 121, s. 147-158.

GÓRALEWICZ-DROZDOWSKA M., GRUSZKA I., 2011, Dzielnica Wzajemnego Szacunku Czterech Wyznań jako nowy produkt turystyczny Wroctawia, Zeszyty Naukowe Uniwersytetu Szczecińskiego, 648, „Ekonomiczne Problemy Usług”, 66, s. 141154.

KOWALSKA M., 2012, Wroctaw - wybrane problemy rewitalizacji Dzielnicy Czterech Świątyń, [w:] Deklinacja odnowy miast. Z dyskusji nad rewitalizacja w Polsce, K. Derejski, J. Kubera, S. Lisiecki, R. Macyra (red.), Wyd. Naukowe Wydziału Nauk Społecznych Uniwersytetu AM w Poznaniu, Poznań, s. 139-151.
KOZŁOWSKI L., 2013, Dziedzictwo żydowskie w Polsce jako potencjalny i rzeczywisty produkt turystyczny, [w:] Wybrane zagadnienia konkurencyjności turystycznej regionów, D. Sokołowski, R. Jaroszewska-Brudnicka (red.), Wyd. Naukowe Uniwersytetu Mikołaja Kopernika, Toruń, s. 161-175.

KRUCZEK Z., 2014, Festiwal Kultury Żydowskiej - megawydarzenie i flagowa atrakcja Krakowa: ocena wydarzenia $z$ wykorzystaniem metody etnografii wirtualnej, [w:] Kultura i turystyka - w kregu wydarzeń, B. Krakowiak, A. Stasiak (red.), Regionalna Organizacja Turystyczna Województwa Łódzkiego, Łódź, s. 105120.

MACIEJEWSKA B., 2008, Spacerownik wrocławski, Agora, Wrocław.

MAŁKOWSKA-BIENIEK E., 2009, Polskie judaika jako magnes turystyczny, ,"Turystyka Kulturowa”, 4, s. 29-62.

"Miejscowy plan zagospodarowania przestrzennego południowo-zachodniej części obszaru Starego Miasta - rejonu ulicy św. Antoniego", nr XXXVIII/2451/05 z 19 V 2005 r., http:// uchwaly.um.wroc.pl/uchwala.aspx?numer=XXXVIII/2451/ 05; 15.10.2016.

Rocznik statystyczny Wrocławia 2014, 2015, GUS, Wrocław.

ROHRSCHEIDT A.M., 2008, Turystyka kulturowa. Fenomen. Potencjat. Perspektywy, GWSHM Milenium, Gniezno.

Ustawa z dnia 7 kwietnia 1989 r. Prawo o stowarzyszeniach, Dz. U. nr 20, poz. 104.

WILKOŃSKA A., 2010, Wspótczesne zainteresowanie turystów judaikami - badania z Krakowa $i$ Łodzi, [w:] Wielokulturowość w turystyce, E. Puchnarewicz (red.), WSTiJO, Warszawa, s. 169184 .

http:/ / bip.um.wroc.pl/artykul/638/23235/atrakcje-turystycznewroclawia; 5.10.2016.

http://fbk.org.pl/new/fundacja/o-fundacji/; 2.10.2016.

http://fbk.org.pl/new/synagoga/historia-synagogi/; 1.10.2016.

https://www.bet-debora.net/activities/8th-conference/; 5.10. 2016.

http:// www.edytastein.org.pl/pl/4-edyta-stein/1-sladamiedyty-stein/; 16.10.2016.

http:/ / www.fundacja4wyznan.pl; 8.10.2016.
Artykuł wpłyną: 18 września 2016 r. Zaakceptowano do druku: 2 grudnia $2016 \mathrm{r}$. 